\title{
Legal Systems and the Rule of Recognition: Discussion of Marmor's Philosophy of Law
}

\author{
Grant Lamond*
}

\section{Introduction}

Andrei Marmor's Philosophy of Law presents a sustained defense of an exclusive legal positivist theory of law, focused on three basic issues-legal validity, legal normativity, and the nature of legal philosophy. ${ }^{1}$ Legal validity is concerned with the general conditions that give some normative content its status as law within a legal system at a particular time. ${ }^{2}$ Legal normativity is concerned with understanding the nature of legal obligation, i.e. with understanding what sort of 'ought' legal obligations create. ${ }^{3}$ This leads to the third basic issue- the nature of legal philosophy itself. Must a philosophical account of law also be an account of what the law ought to be, i.e. is it methodologically committed to forming judgements about the value of law in seeking to understand it? ${ }^{4}$ Marmor aims to establish that the conditions for legal validity, the nature of legal normativity, and the nature of legal philosophy are not dependent on morality, i.e. that they are "detached" from morality and thus that the best understanding of the nature of law is in terms of it being detached from morality. $^{5}$

The book exhibits the many excellences of Marmor's work in legal philosophy. It is forcefully argued, insightful, and engagingly written. It advances new arguments and

\footnotetext{
* University Lecturer in Legal Philosophy, University of Oxford, and Fellow of Balliol College. Email: grant.lamond@law.ox.ac.uk.

${ }^{1}$ A. MARMOR, PHILOSOPHY OF LAW (Princeton University Press, 2011).

${ }^{2}$ Id. $2-5$.

${ }^{3}$ Id. $5-7$.

${ }^{4}$ Id. 7, 109.

${ }^{5}$ Id. $5-10$.
} 
sets existing arguments in a novel context, giving them fresh impetus. In this comment I want to concentrate on two questions: one about the basic issues of legal philosophy, and the other about the nature of the rule of recognition. Although these two questions are independent of each other, there is a link between them, as I hope to show at the end.

\section{Legal Systems}

Marmor identifies, as we have seen, three central issues of general legal philosophy: (1) the conditions of legal validity; (2) the nature of legal normativity; and (3) the nature of legal philosophy itself. But this omits a further central issue: (4) what is the nature of a legal system? This issue is closely related to the first two issues, since validity and normativity are features of rules within legal systems, but it is also relatively independent, since it concerns the features of a normative system that make it a system of a particular kind. Of course, as Marmor points out in his introduction, his book "is not meant to be comprehensive, even in its limited focus", ${ }^{6}$ but he also says that the book "is focused on the philosophical controversies that concern the general nature of law”. ${ }^{7}$ I want to explain why the nature of legal systems is important in itself, that is, in a way that is not simply reducible to the validity and normativity issues, and important even to the focus that Marmor has in his book.

The main reason the nature of legal systems is an important question of general legal philosophy is that laws necessarily belong to systems, as Marmor recognizes. ${ }^{8}$ What makes a rule or a standard a legal rule or a legal standard is that it belongs to a legal system. It is membership in the system that confers the status of law on standards. What general features the conditions of membership possess is the question of legal

\footnotetext{
${ }^{6}$ Id. 11.

${ }^{7}$ Id. 10.

${ }^{8}$ Id. $17-19$.
} 
validity, but legal validity arises within a recognizable legal system. So it is a central question for legal philosophy to provide some characterization of legal systems, i.e. some account of their basic structure, content and functions. Both Austin and Kelsen, for example, devoted considerable attention to it, Austin in terms of an independent political society composed of a sovereign and the subjects of the sovereign, ${ }^{9}$ Kelsen in terms of a coercive social order interpreted as a system of objectively valid norms. ${ }^{10}$ Hart gave the issue less focus, ${ }^{11}$ while Raz developed an account in terms of law as an institutionalized normative system claiming both comprehensive authority over a community and supremacy over other normative systems within that community. ${ }^{12}$

Beyond the substantive issue of what characterizes a social practice as a legal system, there is a further question raised by the nature of legal systems, namely, what sort of account of legal systems a philosophical account is seeking to provide. This is a methodological question, but a different one to the questions Marmor deals with in chapter 5. Marmor says at the start of chapter 5:

first, it is assumed that in spite of variations between different legal systems across time and place, law is a fairly universal phenomenon in human societies, and that it has certain features that are essential or characteristic of law, as such. Second, it is assumed that we can identify and articulate those essential features of law without forming any moral or political judgment about the merits of law or any particular legal institution. ${ }^{13}$

One way of reading these comments is that an account of the nature of a legal system provides a set of necessary conditions that are jointly sufficient for characterizing a social practice as a legal system, or some more complex version of such a set of conditions. In saying that these conditions are "essential or characteristic", there is

\footnotetext{
${ }^{9}$ J. Austin, The Province of JuRisprudence Determined (H.L.A. Hart ed., London, 1954 [1832]), lecture 6.

${ }^{10}$ H. Kelsen, Pure TheOry OF LAW ( $2^{\text {nd }}$ ed., trans by M. Knight, University of California Press, 1967), 30-54.

${ }^{11}$ H.L.A. HART, THE CONCEPT OF LAW ( $3^{\text {rd }}$ ed., Oxford University Press, 2012), 112-23.

12 J. RAZ, THE AUTHORITY OF LAW (2d ed., Oxford University Press 2009), chapter 6, and for his earlier views THE CONCEPT OF A LEGAL SYSTEM (2d ed., Oxford University Press, 1980).

${ }^{13}$ MARMOR, supra note $1,109$.
} 
possibly also a provision for borderline cases that would be regarded as legal systems, but lack one or other of the features involved. ${ }^{14}$ But an important alternative to this sort of approach is something along the lines of Finnis' account of social practices in terms of the "central case" of a phenomenon, i.e. the paradigmatic instances of a practice that provide the "focal" meaning of a concept. ${ }^{15}$ The idea here is that there are instances of legal systems that are more central or core than others, and an account of law should concentrate on the central case, explaining what makes some instances of law central and how they are related to more peripheral instances of the phenomenon. The features that characterize the central case of a legal system need not all be present, or fully shared, by all of the cases that are recognizably legal systems, but their absence indicates the marginality or defectiveness of these instances.

My point is not that a methodology of central cases must be inherently "normative” or value-laden, in the sense that the central or core cases must be those that are chosen for reasons of political morality or for other moral reasons. Hart himself seems, at times, to employ a central case approach to his analysis of various phenomena in The Concept of Law, ${ }^{16}$ whilst regarding his project as "descriptive”. ${ }^{17}$ The point is rather that a central question for legal philosophy is what sort of an account of a legal system is appropriate to its subject matter. Law, after all, is a cultural creation, a social practice, and its manifestations throughout history seem to be quite diverse. How is the multiplicity of forms of law found across times and cultures best approached? Any general account of law will involve an abstraction from the

\footnotetext{
${ }^{14}$ There is a passing comment on borderline cases of law at $i d .70$.

${ }^{15}$ NAtURAL LaW AND NATURAL Rights ( $2^{\text {nd }}$ ed, Oxford Univeristy Press, 2011), 3-18. A further alternative would of course be Dworkin's account of some social practices as “interpretive” (LAW’S EMPIRE, Harvard University Press, 1986, chapters 2 and 3) but this is addressed: MARMOR, supra note 1, 126-30.

${ }^{16}$ Supra, note 11, e.g. 4. At other points Hart writes in terms of necessary and sufficient features for some state of affairs to obtain, e.g. id. 57, 116.

${ }^{17}$ Id. 239-40.
} 
particular instances that are taken to be paradigmatic cases of the phenomenon, so what sort of abstraction is best suited to this task?

As Marmor indicates in the above quotation, for the project of "detachment" to be complete, it would be necessary to show that we can identify the essential features of legal systems "without forming any moral or political judgment about the merits of law". ${ }^{18}$ But what about the nature of the essential features themselves? Marmor allows that we cannot understand social practices without understanding their essential functions or rationale. ${ }^{19}$ In the case of law this includes understanding its essential moral and political functions. ${ }^{20}$ But he denies that attributing such functions to the law need involve a theorist endorsing the value of the practice. ${ }^{21}$ Marmor says:

even if we suggest that an institution serves some moral values, it does not follow that an account of those values and how they rationalize the institution in question is, in itself, a moral account. Suppose, for example, that I ask myself what is the point or purpose of our greeting conventions; and suppose that I suggest that their point has something to do with the need to manifest respect or show some recognition of the worth of our acquaintances. I have not offered here anything that can be called a moral justification of the practice of greeting conventions. I may well hold the view that showing respect in this way is not morally warranted, that it is not a purpose morally worth pursuing. In other words, a functional explanation of the moral point or purpose of a certain practice would not fail if is the case that morally speaking, the practice is not warranted. Such an explanation would only fail if it happens to be false, as a matter of fact. ${ }^{22}$

I want to raise some questions about this line of argument. The argument works if in saying "what is the point or purpose of our greeting conventions" the theorist is saying that our greeting conventions are believed by the participants (i.e. us in this case) to be a way of showing respect or recognize others' worth. ${ }^{23}$ This clearly need

\footnotetext{
${ }^{18}$ MARMOR, supra note $1,109$.

${ }^{19}$ Id. 113.

${ }^{20} I d .113-14$.

${ }^{21}$ Id. 125.

${ }^{22} \mathrm{Id}$.

${ }^{23}$ This point applies equally clearly to a later passage where Marmor notes that we can grasp a value without endorsing it, in discussing the way we can understand the purpose of baroque architecture to be the glorification of Catholicism without having any views about the value of baroque architecture or Catholicism: id. 129-30.
} 
involve no endorsement of the participants' perspective (even if the theorist is herself one of the participants). But if a theorist is claiming that the point of a practice is to show respect, and that this explains and makes sense of other features of the practice, then the account does seem to be offering at least a pro tanto justification for the practice. Perhaps Marmor means that it can still be the case that all-things-considered the practice is not justified, i.e. that there are good reasons not to manifest respect in this way, but that would still concede that the practice has a valuable purpose.

Equally importantly, if a certain type of social practice like law does have some fundamental moral purpose or point, then it would seem that the theorist is committed to the view that a particular social practice cannot be a legal system unless it has this moral purpose or point (or, at best, that it is a very deviant or defective form of "legal” system without it). So if a moral purpose or function is fundamental to the nature of law, then one of the criteria for being a legal system is possessing this moral function. If that were the case, it would not seem to be possible to give a "detached" account of the nature of law, i.e. one that does not invoke substantive moral values.

Perhaps, alternatively, it could be said that a theorist might be attributing some morally valuable purpose to a practice without endorsing the value. She may be saying: "the practice is best understood as having the (purportedly) morally valuable purpose $\mathrm{X}$, and if $\mathrm{X}$ is morally valuable, then the practice has some moral value” whilst suspending judgement about the moral value of $\mathrm{X}$. But this is a curious stance. Why attribute $\mathrm{X}$ to the practice unless (a) $\mathrm{X}$ is a genuine value or (b) the participants can be understood as regarding the purpose of the practice as $\mathrm{X}$ ? If $\mathrm{X}$ is not really valuable, and if the participants cannot be understood as endorsing $\mathrm{X}$ as the purpose of the practice, how could $\mathrm{X}$ provide the best understanding of the practice? 
On the other hand, as Marmor points out, not all functional explanations need invoke a morally valuable function. To say a cell phone is "useful" would normally be taken to be an endorsement of its value, but cell phones can be used for deplorable as well as desirable purposes. ${ }^{24}$ That something has morally desirable uses does not show that it has moral value unless it is being used in that way. This is true, but consider a different tool—a scalpel. A scalpel is a knife designed for use in surgery to enable the surgeon to better treat patients. The proper purpose of a scalpel is (on most views) a morally valuable one. But a scalpel can be used to perform unnecessary surgery, or as a knife to attack or threaten others. Does this show that the point or purpose of a scalpel is value-neutral, i.e. that it all depends on how it is being used? Or does it just show that these are misuses and abuses of the tool? That social practices can be misused or abused does not show that they lack a proper moral function that is intrinsic to the nature of the practice.

If the point or purpose of law is to perform some morally valuable function, it does not follow that actual legal systems successfully discharge this function. But it would show that they are defective as legal systems because of this moral failing. We can of course criticize legal systems whether or not law has a moral point or purpose: some will be morally better or worse in the ways they treat their subjects and advance morally desirable ends. So I am not saying that law does have such an inherent or intrinsic moral function, i.e. that law has a morally "proper” purpose. I am skeptical that at a level of abstraction of a general theory of law, covering highly diverse historical periods and cultural settings, that this is the case. But I think it is an important issue in general legal philosophy whether or not law does have such an intrinsic or inherent morally valuable purpose. It may be I have not fully understood

\footnotetext{
${ }^{24}$ Id. 125.
} 
Marmor's arguments, but as far as I can tell a theorist who attributes a morally valuable proper purpose to a social practice is not really offering a detached account of the social practice. Instead, a detached account must attribute some functional purpose to the law that is not necessarily valuable, or attribute a purpose to the practice on the basis that this is how the participants understand the practice.

\section{The Rule of Recognition as a Conventional Rule}

One of the most original and important arguments that Marmor has developed over a number of years is that Hart's rule (or rules) of recognition are conventional rules: not because they amount to co-ordination conventions but because they are constitutive conventions. ${ }^{25}$ I want to raise two questions about this account: one about the role of general conformity, and the other about the legal status of the rule of recognition.

\section{The role of general conformity}

Mamor summarizes his views at the end of chapter 3:

(1) In every society that has a functioning legal system there are some social conventions that determine who counts as legal authority in that society and how its authority is to be exercised.

(2) Legal norms consist of the directives or instructions of legal authorities, namely, those authorities which are identified and constituted by the social conventions of (1). ${ }^{26}$

The social conventions referred to in (1) are the rules of recognition in a legal system.

By a "social convention”, is meant the following:

A rule, $R$, is conventional, if and only if all the following conditions obtain:

(1) There is a group of people, a population, $P$, that normally follow $R$ in circumstances $C$.

(2) There is a reason, or a combination of reasons—call it $A$-for members of $P$ to follow $R$ in circumstances $C$.

(3) There is at least one other potential rule, $S$, that if members of $P$ had actually followed in circumstances $C$, then $A$ would have been a

\footnotetext{
${ }^{25}$ This is argued for in detail in A. Marmor, Social Conventions: From LANGUAGE TO LAW (Princeton University Press, 2009), chapters 1-3 and 7.

${ }^{26}$ MARMOR, supra note $1,83$.
} 
sufficient reason for members of $P$ to follow $S$ instead of $R$ in circumstances $C$, and at least partly because $S$ is the rule generally followed instead of $R$.

The rules $R$ and $S$ are such that it is impossible (or pointless) to comply with both of them concomitantly in circumstances $C .{ }^{27}$

What this amounts to is the claim that a rule is conventional when (a) it is followed by a group, (b) there is another possible rule that could have been followed, (c) the reasons for following the rule would have equally supported following the other possible rule, and (d) there would be no point in following the rule if it was not generally followed by others. The intuitive thought here is that a conventional rule is arbitrary, in the sense that there is another rule that could have been followed to achieve much the same purpose; and secondly that that there is no point in following a conventional rule if it is not generally followed in the relevant population. ${ }^{28}$

One question about this account concerns the role that general conformity to a conventional rule plays in the rationale for following the rule. Is the fact that a rule is generally followed a positive reason for following it, or is it simply a negative reason for following it? What's the difference? A positive reason would be one that takes general use of the rule as providing a reason for doing so, whereas a negative reason merely says that if the rule was not generally followed there would no longer be any point in following it. Another way of putting the point is to ask whether general conformity is one of the grounds for following the rule, or is merely a condition for following the rule. (It could be both a ground and a condition, of course, but that doesn’t change the thrust of the point.)

In a co-ordination convention, such as driving on the road, the fact that a community generally drives on one side of the road is normally the ground for doing the same. There is of course a further reason for doing as others do, in making driving far safer

\footnotetext{
${ }^{27}$ Id. 77.

${ }^{28}$ Id. 76.
} 
than it would be otherwise; but the reason for driving on the left or right as it may be, is that this is what everyone else does. Safety on the road, then, is the operative reason for driving on the same side as others. The auxiliary reason for driving on the left (or right) is that this is the side that others drive on, i.e. it is the state of affairs to which the operative reason applies. ${ }^{29}$

In other cases, by contrast, general conformity seems to function as a condition rather than a ground. Take the case of using capital letters at the beginning of sentences in written English. This is a rule of English grammar, and there are various reasons for the rule, such as making it clear when a new sentence is commencing, though this could be achieved in other ways (e.g. a vertical line before the first letter). Now in this case, general conformity to the rule seems to be part of what makes this a rule of current English grammar: if it were no longer generally followed it would cease to be a rule of grammar. But the basic reason for following the rule would normally be put in terms of it being ungrammatical not to do so. If further reasons were sought for following the rule, it might be said that it would be confusing not to, or would seem ill-educated. The function of the rule, it might be said, is to aid communication and avoid misunderstanding by clearly marking the beginning of sentences. General conformity, then, is certainly necessary for the rule to be a rule of grammar, but it would not normally be put forward as one of the grounds for following the rule. A grammatical rule is not just what is generally done, though that is necessary for it to exist.

So one question about the rule of recognition is whether general conformity to it forms part of the grounds for officials to follow it, or simply a condition for the rule to

\footnotetext{
${ }^{29}$ On operative and auxiliary reasons see J. RAZ, PRACTICAL REASON AND NORMS ( ${ }^{\text {nd }}$ ed., Princeton University Press, 1990), 33-5.
} 
exist. Hart does not address this question directly in The Concept of Law, ${ }^{30}$ though it might be thought that what he says about the nature of social rules makes it a ground. For Hart, the internal point of view (the point of view of those who accept a social rule) involves criticism of others' deviations from the rule and regarding criticism of one's own deviations as justified. That a social rule is generally followed provides one with a reason to conform to the rule in order to avoid criticism and other forms of social pressure. But of course, these are not the reasons for having the social rule in the first place, and they only apply when there is a risk of detection and such reaction. (Similarly, these types of considerations do not satisfy Marmor's account of the reasons for following a conventional rule-reasons $A$ in (2) above.)

Hart leaves it open whether he thinks general conformity to the rule of recognition provides grounds for following it or is merely a condition for following it. And it's not clear from the text of Marmor's books which view he takes either. He says:

there is a very clear sense in which the reasons for following the rules of recognition are compliance-dependent in the relevant sense. This is one of the points that Hart has rightly emphasized in his postscript to The Concept of Law - that the reasons judges and other officials have for following certain norms about the identification of the sources of law in their legal systems are closely tied to the fact that other officials follow those same norms. ${ }^{31}$

There are reasons for thinking that in the case of the rule of recognition compliancedependence is simply a condition on following it, rather than a ground. The difference between general conformity being a ground or a condition seems to reflect the difference between conventional rules that are one-off, or relatively individual, from rules that belong to a recognized system of rules which has a general rationale. ${ }^{32}$ In

\footnotetext{
${ }^{30}$ Supra note 11. For a detailed analysis of Hart's views in THE CONCEPT OF LAW see J. Dickson, Is the Rule of Recognition Really a Conventional Rule? 27 OXFORD J. LEGAL STUD. 373 (2007).

${ }^{31}$ MARMOR, supra note $1,81$.

${ }^{32}$ Not all "bodies" of rules have a general, overarching rationale. The rules of etiquette, for instance, seem to be a haphazard set of standards dealing with a variety of social contexts, e.g.
} 
the case of one-off rules, general conformity is directly relevant to the grounds for following the rule. Where there is a system of rules, on the other hand, the reasons for following a rule that belongs to the system are the reasons for having such a system of rules as a whole. A system of rules may be entirely customary, such as the rules of grammar, in which case general conformity is a condition of the existence of each rule. In cases like law, on the other hand, where some rules are validated by other rules, validation may be sufficient for being part of the system of rules. Un-validated rules of the system such as the rule of recognition, by contrast, must be practiced in order to exist. Being practiced is, however, simply a condition for them being followed, not one of the grounds for doing so. The ground for following them is that they are rules of the system, and there are reasons for following the system.

\section{The legal status of the rule of recognition}

Another question about Marmor's analysis of the rule of recognition concerns the legal status of the rule of recognition. Marmor argues that Hart's rule of recognition is essentially the same as Kelsen’s basic norm, but with it characterized reductively in terms of social rules. ${ }^{33}$ They perform basically the same theoretical function. ${ }^{34}$ What is that function?

As we have already seen in the previous chapter, a legal chain of validity always comes to an end. In every legal system we reach a point where some account must be given, in non-legal terms, to explain what grants certain actions and events the legal significance that they have. There must be something more basic or foundational that grounds the very idea of legality. ${ }^{35}$

Later Marmor says:

Hart clearly shares Kelsen's insight that the only way in which we can explain the idea of legality is by pointing to norms which grant certain types

dress, greetings, laying cutlery, manner of eating. Here the reasons for following a rule is often just that this what everyone does in our community.

${ }^{33}$ MARMOR, supra note 1, 51.

${ }^{34}$ Id. 50.

${ }^{35}$ Id. 49. 
of actions and events the legal significance that we ascribe to them. There must be some norms which identify the ways in which law is created and modified in the relevant community. These are the rules of recognition. ${ }^{36}$

Legal validity - the status of a rule as a legal rule-depends upon another rule that confers that status upon it. The law is composed of chains of validity that are hierarchically organized. But the chain must come to an end somewhere, with what can be called the ultimate criteria of validity in a legal system. The ultimate criteria give other rules their legal status, but there is no rule to give the ultimate criteria their legal status. Of course Kelsen’s and Hart's views about the ultimate criteria of validity differ. Kelsen argues that the ultimate criteria of validity are themselves valid norms, and so the basic norm must be presupposed to account for their validity. ${ }^{37}$ Hart argues that the ultimate criteria of validity are not "valid", but are instead social rules accepted by the officials of a legal system. ${ }^{38}$ The ultimate criteria of validity are part of the rule of recognition. ${ }^{39}$ Consequently, Hart regarded the rule of recognition as a "legal” rule only in a special sense, as the basis for the identification of the rules of the system. ${ }^{40}$

Now if the rule of recognition is a social/conventional rule, a key question is why it is binding. Hart argued that "rules of recognition specifying the criteria of legal validity ... must be effectively accepted as common public standards of official behaviour by its officials." ${ }^{41}$ But Hart never explained why it is accepted, and seems to have been of the view that it could accepted for any (or at least a wide variety of) reason(s). The

\footnotetext{
${ }^{36} I d .55$.

${ }^{37}$ KELSEN, supra note 10, 198-205.

${ }^{38}$ HART, supra note $11,107-10$.

${ }^{39}$ Id. 101, 105-8, 111, 293. Hart argues that every legal system has only one ultimate rule of recognition containing the criteria of validity (see Lon L Fuller: The Morality of Law, EsSAYS IN JURISPRUdENCE AND PhILOSOPHY (Oxford University Press, 1983), 360). This is controversial (see RAZ, supra note 29, 146-8, CONCEPT OF A LEGAL SYSTEM, supra note 12, 200 and AUTHORITY OF LAW, supra note 12, 95-6) but does not affect this discussion.

${ }^{40}$ HART, supra note 11, 111-12.

${ }^{41}$ Id. 116.
} 
reasons for following the rule of recognition were non-legal reasons, since it was the rule of recognition that provided the reasons for following the law it identified. ${ }^{42}$

Marmor's solution to this question is different:

The legal obligation to follow the rules of recognition is just like the chess players' obligation to, say, move the bishop-if one is to move it-only diagonally. Both are prescribed by the rules of the game. What such rules cannot prescribe, however, is an "ought" about playing the game to begin with. ...

The sense in which a judge is obliged to follow the rules of recognition is exactly like the obligation of an umpire in a cricket game to follow the rules of cricket. Both obligations are conditional. If, and to the extent that the judge or the umpire have reasons to play the game, the rules simply determine what their obligations in the game are; they constitute what the game is. ${ }^{43}$

If I understand Marmor's brief remarks correctly, then:

(a) there is a legal obligation on judges to follow the rule of recognition, i.e. a reason internal to the practice of law

(b) whether someone should adopt the role of a judge and take part in the practice depends upon ordinary moral reasons

The rule of recognition, then, is a legal rule, and is to be followed by judges and officials because it is legally binding to do so. But this is difficult to square with the earlier comments that "In every legal system we reach a point where some account must be given, in non-legal terms, to explain what grants certain actions and events the legal significance that they have”. ${ }^{44}$

Is there a conflict here between these two views? On the face of it, yes, but I think that there is a way of preserving both of Marmor's insights into the nature of the rule of recognition. Instead of thinking that there is a conflict between the rule of recognition being both a legal rule and a social convention, there is a way of bringing them

\footnotetext{
42 The text of THE CONCEPT OF LAW is not entirely clear about this (though see id. 116 and 235), but Hart explicitly endorsed this reading in Legal Duty and Obligation in ESSAYS ON BENTHAM (Oxford University Press, 1982), 155-6, 160-1.

${ }^{43}$ MARMOR, supra note 1,82 , and see generally 81-3.

${ }^{44}$ Id. 49.
} 
together: by understanding the rule of recognition as customary law of the courts (or custom in foro, as Bentham dubbed it). ${ }^{45}$ Customary law of the courts combines the two features which Mamor identifies as central to the rule of recognition: that they are legal rules which the courts and officials are legally bound to follow, and that they are social conventions, in part because being generally followed by the officials is a condition of their existence. Customary law of the courts differs from the more often discussed custom in pays ${ }^{46}$ _ customs of non-officials that are identified by the rule of recognition itself. ${ }^{47}$ It is a contingent question whether a legal system identifies custom in pays as binding law. By contrast, the rule of recognition is necessary for there to be any source-based law, so there must be some customary law of the courts for there to be source-based law. Understanding the rule of recognition as customary law of the courts explains the fact that officials treat the ultimate criteria of validity in their systems as law like any other law, i.e., not simply as part of a judicial custom (a social convention of the judiciary) but as authoritative legal standards that judges qua judges are bound to apply. ${ }^{48}$

To complete the picture, however, requires two additional points. As argued above, the reasons for following the rules that belong to a system rests on the reasons for having that system at all. In a sense I agree with Marmor that "if there are reasons to have rules of recognition, those reasons must be very intimately linked to the reasons for having law and the main functions of law in society." 49 Ultimately, it is the reasons for having that body of rules which provides the reasons (if any) for following

\footnotetext{
45 J. BENTHAM, A COMMENT ON THE COMMENTARIEs, (J.H. Burns and H.L.A. Hart eds, Oxford University Press, 1977), 182-4.

${ }^{46} \mathrm{Id}$.

${ }^{47}$ This is the only sort of customary law that Hart discusses in THE CONCEPT OF LAW, supra note 11, 44-8, 100, 101.

${ }^{48}$ For a more detailed analysis of customary law of the courts see G. LAMOND, Legal Sources, the Rule of Recognition and Customary Law, 59 AMERICAN JOURNAL OF JURISPRUDENCE (2014 forthcoming), section III.

${ }^{49}$ MARMOR, supra note 1, 78-9.
} 
the particular rule. The legal reason for officials qua officials to follow the rule of recognition is that it is part of the law, and officials are legally duty-bound to follow the law. But this is no different from the legal reason for following any other legal rule: the rule of recognition is part of the law, and so is legally binding.

Whether there is a good moral reason for following the law, however, is a different question. The position of an official is particularly complex. Marmor agrees that law claims practical authority over a population: ${ }^{50}$ whether it has the legitimacy to do so is a question of political morality. ${ }^{51}$ It may be that only some (or even no) legal duties create even pro tanto moral reasons, or only create moral reasons for some members of the population. ${ }^{52}$ Whether someone should adopt the role of a judge is a related but separate question. There may be good moral reasons for becoming a judge in even an illegitimate legal system (e.g. to preserve what is worthwhile in the law, or to use the position to do some good), just as it may be quite permissible not to become a judge in a legitimate legal system. Whether the rule of recognition is pro tanto morally binding on officials because it is part of the law depends ultimately upon whether it is a justifiable part of a legal system that is pro tanto morally binding. Judges who accept the moral legitimacy of their legal systems, of course, tend to believe that they have a moral responsibility (and not just a legal duty) as judges to apply all of the laws of the system. But the basic point is clear enough: the ultimate justification for following and applying the law must be reasons of political morality.

The second point that needs to be made about the rule of recognition is this. The answer to the question of "what grants certain actions and events the legal

\footnotetext{
${ }^{50}$ Id. $60-73$

${ }^{51} I d .72-3$.

${ }^{52}$ E.g. J. RAZ, The Morality OF FrEedOM (Oxford University Press, 1986), chapter 4.

There may, of course, be collateral moral reasons for following laws that lack legitimacy.
} 
significance that they have", ${ }^{53}$ is to be found in the analysis of legal systems, rather than the rule of recognition. The rule of recognition plays a subordinate and auxiliary role in granting actions and events their legal significance. Actions and events have legal significance because there is a system of rules that gives such actions and events a characterization according to those rules, and the system of rules amounts to a legal system. What grants certain actions and events their legal significance, then, is the way that they are characterized by (the rules of) a legal system. The rule of recognition plays a key role in a legal system, but when it comes to the point where "some account must be given, in non-legal terms" 54 to explain the legal significance of certain actions and events, that account should be in terms of what makes a social practice a legal system, rather than in terms of the nature of the rule of recognition.

\section{Conclusion}

Mamor's Philosophy of Law is a forceful and engaging argument for an exclusive legal positivist account of the law. It synthesizes and advances the case for such a theory. In this comment I have highlighted a number of significant points where I think the arguments go astray or need modification, but the book sets a new benchmark for those interested in the general theory of law, and more than fulfils its promise of providing a basis for "fruitful disagreement". ${ }^{55}$

\footnotetext{
${ }^{53}$ MARMOR, supra note $1,49$.

${ }^{54}$ Id. 49.

${ }^{55}$ Id. 11.
} 